\title{
A REFINEMENT OF THE DISCRETE JENSEN'S INEQUALITY
}

\section{LÁSZLó HORVÁTH AND JOSIP PEČARIĆ}

Abstract. We give a refinement of the discrete Jensen's inequality in the convex and mid-convex cases. For mid-convex functions our result is a common generalization of known inequalities. We illustrate the scope of the results by applying them to some special situations.

Mathematics subject classification (2010): 26D07 (26A51).

Keywords and phrases: Convex, mid-convex, Jensen's inequality.

\section{REFERENCES}

[1] S. S. DragomiR, A further improvement of Jensen's inequality, Tamkang J. Math., 25, 1 (1994), 29-36.

[2] C. GaO AND J. Wen, Inequalities of Jensen-Pečarić-Svrtan-Fan type, J. of Inequal. Pure Appl. Math., 9, 3 (2008), Article 74, 8 pp.

[3] G. H. Hardy, J. E. Littlewood and G. Pólya, Inequalities, Cambridge Mathematical Library Series, 1967, Cambridge University Press.

[4] L. Horváth, Inequalities corresponding to the classical Jensen's inequality, J. Math. Inequal., 3, 2 (2009), 189-200.

[5] D. S. Mitrinović, J. E. PeČArić And A. M. Fink, Classical and new Inequalities in Analysis, Kluwer Acad. Publ., Dordrecht-Boston-London, 1993.

[6] J. E. PEČARIĆ, Remark on an inequality of S. Gabler, J. Math. Anal. Appl., 184 (1994), 19-21.

[7] J. E. PEČARIĆ AND D. SVRTAN, New refinements of the Jensen inequalities based on samples with repetitions, J. Math. Anal. Appl., 222 (1998), 365-373.

[8] J. E. PeČArić And D. SVRTAn, Unified approach to refinements of Jensen's inequalities, Math. Inequal. Appl., 5 (2002), 45-47.

[9] J. E. PeČARIĆ AND V. VOLENEC, Interpolation of the Jensen inequality with some applications, Österreích. Akad. Wiss. Math.-Natur. Kl. Sitzungsber., II 197, 8-10 (1988), 463-467.

[10] X. L. TANG AND J. J. WEn, Some developments of refined Jensen's inequality, J. Southwest Univ. of Nationalities (Natur. Sci.), 29, 1 (2003), 20-26. 